\title{
Estimate of Financial Benefits from Value Chain of Bến Tre Coconut
}

\author{
TRẦN TIẾN KHAI \\ Doctor of Philosophy, University of Economics HCMC \\ Email: trankhai565@yahoo.com \\ HỒ CAO VIẸTT \\ Doctor of Philosophy, Email: hocaoviet2000@yahoo.com \\ LÊ VĂN GIA NHỎ \\ Master of Arts, Institute of Agricultural Science for Southern Vietnam \\ Email:nholvg@yahoo.com \\ NGUYẼ̃N VĂN AN \\ Master of Arts, University of Economics HCMC, Email: antuyhoa@yahoo.com \\ HOÀNG VĂN VIỆT \\ Master of Arts, University of Economics HCMC, Email: viet.hoangvan@ueh.edu.vn \\ NGUYẼ̃N VĂN NIẸM \\ Master of Arts, Bến Tre Department of Science and Technology \\ Email: hoainiembentre@yahoo.com.vn
}

\begin{abstract}
Coconut has long played an important role in Bến Tre economy. Understanding and estimating exactly contribution from the value chain of coconut are still limited. This paper tries to analyze the structure and operation of the value chain of coconut and estimate its contributions in financial aspects. The paper employs value chain approach and analyzes the added value, and applies both quantitative and qualitative analyzing methods for entities engaging in growing, processing and commercializing products from coconut. The results confirm financial benefits generated by the coconut.
\end{abstract}

Keywords: value chain, coconut and products from coconut, added value 


\section{PROBLEM STATEMENT}

Bến Tre is an agricultural province in the Mekong Delta whose natural conditions are favorable for agricultural development. Bến Tre economy is based on sea-farming and orcharding. Its staple products include fish, shrimps, clam, catfish, coconut products, rice, sugarcane, livestock and poultry. Of agricultural plants, the main ones are coconut, fruit and rice.

Bến Tre government has recently taken measures to develop its staple agricultural products by diversifying processed farm products, generating more new jobs, and supporting development of value chain of farm products.

Coconut is an important plant in Bến Tre and contributes a lot to local economy. In the past, however, there has been no research on its contribution to the economy and operations relating to production and sale of coconut products.

This research on value chain of Bến Tre coconut aims at understanding the structure of value chain and its operations at present time, and commercial and economic relations between participants in the value chain. The research also examines diverse products made from coconut and estimates potentials for generating income and contributions by coconut products to local economy.

\section{DATA AND METHODOLOGY}

This research employs analyzing framework for value chain developed and introduced by international development agencies, such as German GTZ and U.S. ACDI/VOCA and "making markets work for the poor" project (M4P) based on theories of value chain and product lines. Methodology of product line analyzing suggested by the FAO is also used in this research.

In this paper, the term "value chain" refers to all operations that aim at producing a product/service and bring it to end consumer. The value chain involves direct and indirect entities that engage in production, processing and distribution of a product. The value chain of a farm product involves many direct entities, such as supplier of farming materials, producer, local trader, processor, wholesaler, exporter; and indirect ones, such as supplier of public services and partners in private sector.

Various quantitative and qualitative methods are used to analyze the value chain of Bến Tre coconut. Qualitative analyzing methods include purposive sampling, open data collection, analysis of texts and secondary data, summarizing meanings and 
explaining results, interview with experts, case studying and observation. Some quantitative methods are statistical investigation, cost-profit analysis, and analysis of added value in each stage and the whole chain along principal product channels.

The research employs the non-probability sampling, namely, proportionate quota sampling along with convenience sampling, based on coconut areas in main districts in Bến Tre. The sample comprises 120 coconut planters: 56 of them plant industrial coconut (selling dried coconut); 32 sell fresh coconut; and 32 are developing their coconut orchards. Authors also interview 20 local traders; 10 concerns that purchase and process coconuts; five producers of pre-activated coconut shell charcoal; 10 processors of coconut fiber; three producers of nata de coco; two producers of coconut candy; one producer of handicrafts from coconut; and five producers of coconut products for export. The research was carried out in 2011 and numerical data were collated in 2010.

Cost-profit analysis and added value analysis are conducted using common indicators such as sales, total cost, variable cost, fixed cost, production cost, profit, household income, cost of intermediate goods, and added value, etc. Cost of production of coconut during the first five years is expressed in the 2010 price used for working out amortization for crops in the next 20 years. In this paper, the added value is used as a general indicator for the whole value chain of coconut.

Calculation of added value of different channels of coconut products in the chain is conducted according to the following steps, as suggested by FAO (2005):

Step 1: Establishing account sheet for each participant in the product channel;

Step 2: Combining participants' account sheets into a gross account sheet

Step 3: Analyzing the gross account sheet

Individual account sheets and the gross account sheet are presented in Figures 1 and 2.

\section{RESEARCH RESULTS}

\section{a. A Diagram of Value Chain of Bến Tre Coconut:}

Value chain of Bến Tre coconut (Figure 3) relies on links between planters, traders and coconut processing concerns. Entities that support them are suppliers of farming materials, market information and scientific services; commercial banks; trade and 
investment promotion agencies; agricultural authorities, trade association; and research centers.

Entities that play important roles are coconut planters; purchasers and processors of coconut; and producers of main product (coconut meat) and by-products (shell, coconut water, coconut fiber, and coconut timber, etc.).

The value chain of Bến Tre coconut starts with supplier of farming materials (fertilizer, pesticide, farming tools, etc.). Coconut planters usually own small farms and sell either immature or mature coconuts. Local traders develop wide networks to purchase coconut from farmers in all districts and sell them to processing concerns.

Coconut processing concerns in Bến Tre undertake dehusking the fruit, and separating meat and coconut water from the shell, and sell these semi-processed products to exporters and larger processing factories that turn the raw materials into various products for both domestic and foreign markets.

\section{b. Direct Participants in the Value Chain:}

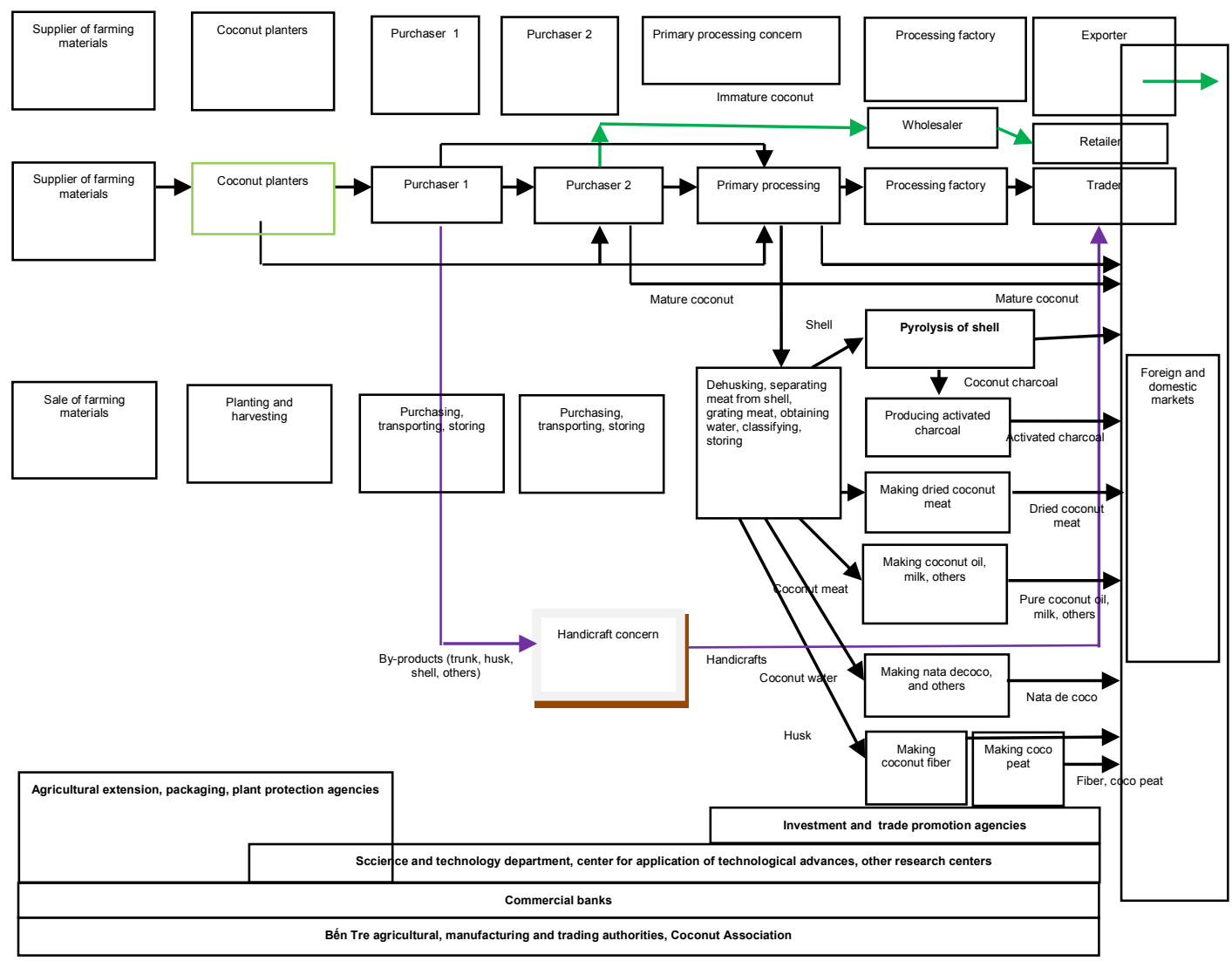

Figure 3: Value Chain of Bến Tre Coconut 


\section{- Coconut planter:}

Labor market provides coconut planters with farm hands needed for planting and harvesting coconut. Suppliers of farming materials provide fertilizer, pesticide and other farming tools. Local traders and purchasers of all levels (hamlet, commune, district and province) buy coconut output all year round.

The average yield obtained by surveyed farmers is 10,642 shells of mature coconut per hectare per year, 17,000 immature coconuts per hectare per year. The yield of immature coconut is 1.7 times higher than that of mature shells. Difference in the yield of immature coconut over farms is wider than the yield of mature coconut. Pretty high coefficient of variation of coconut yield (from 35\% to 52\%) shows that the yield varies over farms, which comes from various causes (seed, density of trees in the farm, age of coconut trees, farming techniques, soil quality, and use of pesticide, etc.).

Production cost per coconut shell in 2010 was less than VND3,000, much lower than the selling price, which ensures planters an average profit of VND48 million for a hectare of immature coconut, and around VND43 million for a hectare of mature coconut. Production of immature coconut, however, requires larger investments (1.6 times higher than investment in production of mature coconut) in fertilizer and labor. Regarding household profit (including profit and opportunity cost for family labor), a hectare brings in VND60 million a year from immature coconut; or VND49 million from mature coconut.

Generally, added value generated by mature coconut is 1.54 times higher than that produced by immature coconut because price of mature coconut is higher (VND6,000 compared with VND4,000 for a fruit of immature coconut) while intermediate expenses is as high as 1.2 times only.

\section{- Purchaser of mature coconut:}

Purchasers of mature coconut for industrial purpose are important entities who act as a link between planters and processing concerns and exporters of coconut products.

These purchasers are usually local farmers who engage in coconut trading as an additional occupation and get full information about harvest of coconut in any farm in the district, and prices for all classes of coconut. They are usually divided into two levels: purchasers of level 1 buy coconut from farmers and sell to purchasers of level 2 who have good relations with coconut processing concerns. 


\section{- Coconut primary processing concern:}

Primary processing is the first stage in the production of coconut products, an importantly intermediate stage that links farmers and purchasers with industrial processing factories. These concerns also supply coconut shells to Chinese importers, and therefore, they exert some impacts on prices of coconut as raw materials for processing factories.

Purchasers and primary processors buy mature coconut or coconut shell (or dehusked coconut) and carry out three stages: dehusking; breaking the shell to obtain coconut water and coconut meat; and removing the thin brown layer between the meat and the shell to obtain the white coconut meat to be stored. They may otherwise sell dehusked coconut to Chinese purchasers who act as agents for Chinese importers. Some $75 \%$ of primarily processed coconut is sold to processing factories in Bến Tre; $12.5 \%$ sold to factories in other provinces and the remaining $12.5 \%$, in form of dehusked coconut, is sold to Chinese purchasers. Principal products and by-products from primary processing concerns available in provincial marketplaces include white coconut meat that can be turned into dried coconut meat and other products; coconut water needed for making nata de coco; coconut shell to be tuned into charcoal or activated charcoal; coconut husk used for making coconut fiber and coco peat; and the thin brown layer of coconut meat to be turned into coconut oil or feed.

- Dried coconut producing concern:

In Bến Tre today, there are over 20 dried coconut producing concerns. Their outputs are for both domestic and foreign markets. They are important players in the value chain because they generate high added values and put great investments in industrial technologies and managerial skills. They can be divided into two groups: (1) producers of dried coconut for export; and (2) producers of dried coconut and other by-products (pure coconut oil, charcoal...) for domestic market.

Export markets for these concerns are mostly Islamic countries in Southeast Asia and South Asia, and other countries in Middle East, Europe and America. Their main potential markets are EU countries, South Africa, the U.S. and China. According to Bến Tre Statistics Office, dried coconut from Bến Tre was sold to 36 countries in 2009.

Dried coconut producing concerns can play the role of a dynamic that helps the coconut industry in this province to develop. They determine the technological level of 
the processing business and expansion of export markets for coconut products from Bến Tre. From producing dried coconut, these concerns may invest in new technologies to make products of higher use and added values, and ensure a better economic efficiency for the whole industry.

- Concerns producing coconut fiber and coco peat:

These concerns purchase husk from primary processing concerns or purchasers and turn it into fiber and export it mainly to China. Part of their output may be sold to local concerns that produce rope, thread, net, or handicrafts, etc.

Coco peat is usually sold to packaging concerns that make it into blocks with humidity of $10 \%$ at most and export it to South Korea, Japan and China. Coco peat is used for producing clean land, cultivating medium or floor fillers used for poultry farms.

\section{- Producers of shell charcoal and activated charcoal:}

Coconut shell is used for producing charcoal and sold to concerns making preactivated charcoal (ground and sieved shell charcoal) and selling it to foreign importers and producers of activated charcoal. According to a rough estimate, $75 \%$ of shell charcoal output is used for making activated charcoal and $25 \%$ is sold to Chinese importers. According to Bến Tre Statistics Office, Bến Tre exported 16,500 tonnes of pre-activated charcoal and China bought $98.8 \%$ of this volume.

- Producers of nata de coco:

Producers of nata de coco buy coconut water extracted from mature coconut and condense it to make raw nata. There are two groups of buyers of the raw nata. The first include producers of finished nata de coco to be sold to end users; or processors of raw nata into some kinds of raw materials for other food processing concerns. This group consumes about $10 \%$ of Bến Tre nata output. The second group comprises exporters who sell raw nata to surrounding markets, especially Taiwan. This channel consumes $90 \%$ of nata output.

\section{c. Financial Efficiency of some Channels for Coconut Products:}

- Immature coconut:

Value chain of immature coconut (Table 2) gains VND5.845 million for 1,000 shells; or over VND99 million for a hectare of coconut. This revenue is pretty higher than those for other plants. Expense on intermediate goods needed for producing 
immature coconut only equals a small part of revenue because added value accounts for the better of the revenue. This channel therefore generates high added value for planters and other participants. Such indicators as P/IC, VA/IC and NPr/IC show that planning and trading immature coconut employ mostly local resources (land, labor and capital) and only depend slightly on external resources (see Table 3).

- Mature coconut for export:

Value chain of mature coconut for export (Table 2) gains VND10.045 million (about US\$515) for 1,000 shells; or over VND106.48 million (about US\$5,461) for a hectare of mature coconut with an average yield of 10,600 shells a year. Expense on intermediate goods needed for producing mature coconut only equals a small part of revenue because added value accounts for the better of the revenue. Such indicators as $\mathrm{P} / \mathrm{IC}, \mathrm{VA} / \mathrm{IC}$ and NPr/IC show that planning and trading mature coconut enjoy favorable competitive advantages based on local resources (land and labor) and do not require big investments (see Table 3 ).

- Primarily processed mature coconut:

According to our calculation, in the value chain of primarily processed mature coconut (Table 2), revenue from 1,000 mature shells for export is lower than that in the value chain of mature coconut for export when competition for shells as raw materials exists. When coconut is not exported, however, other primarily processed products, such as meat, water, and shells can be processed further to generate more added value. When it is exported, on the other hand, revenue from export of coconut may be higher than revenue from coconut primarily processed in Bến Tre; but this practice generates no more added values.

Table 2: Financial Efficiency of some Channels for Coconut Products in 2010

\begin{tabular}{|c|c|c|c|c|c|c|}
\hline \multirow[b]{2}{*}{ Item } & \multicolumn{4}{|c|}{ Immature coconut ( 1,000 shells $)$} & \multicolumn{2}{|c|}{ Per hectare* } \\
\hline & $\begin{array}{c}\text { Value } \\
\text { (VND1,000) }\end{array}$ & $\begin{array}{l}\text { Value } \\
\text { (USD) }\end{array}$ & $\begin{array}{l}\text { As \% of } \\
\text { revenue }\end{array}$ & $\begin{array}{c}\text { As \% } \\
\text { in } \\
\text { IC,VA }\end{array}$ & $\begin{array}{l}\text { Value } \\
\text { (VND } \\
\mathbf{1 , 0 0 0 )}\end{array}$ & $\begin{array}{l}\text { Value } \\
\text { (USD) }\end{array}$ \\
\hline \multicolumn{7}{|c|}{ Channel 1: Immature coconut from planter to purchaser of level 2 in Bến Tre City } \\
\hline 1.Revenue $(\mathrm{P})$ & 5,845 & 299.7 & 100 & & 99,365 & 5,096 \\
\hline 2. Intermediate cost (IC) & 459 & 23.5 & 7.9 & 100 & 7,803 & 400 \\
\hline
\end{tabular}


3. Added value (VA)

- Net profit (NPr) (planter)

- Net profit (NPr) (purchaser 1)

- Net profit (NPr) (purchaser 2)
5,386

2,603

517

547
$276.2 \quad 92.1$

26.5

28.1
$133.5 \quad 48.3$
9.6

10.2
100

48.3

9.6

8,789

451

\section{Channel 2: Mature coconut for export from planter to purchaser 2}

1.Revenue (P)

2. Intermediate cost (IC)

10,045

515.2

100

$106,484 \quad 5,461$

3. Added value (VA)

545

9,500

28.0

5.4

100

5,780

296

- Net profit (NPr) (planter)

4,502

48.,2

94.6

100

100,703

5,164

230.9

47.4

47,721

2,447

- Net profit (NPr) (purchaser 1)

490

25.1

$5.2 \quad 5,194$

266

- Net profit (NPr) (purchaser 2)

2,904

148.9

$30,783 \quad 1,579$

\section{Channel 3: Mature coconut from planter to primary processing concern}

1.Revenue (P)

2. Intermediate cost (IC)

3. Added value (VA)

- Net profit (NPr) (planter)

- Net profit (NPr) (purchaser 1)

- Net profit (NPr) (purchaser 2)
9,127

500

8,627

4,502

490

1,629
468.1

100

25.7

442.4

230.9

25.1

83.6

5.5

94.5
$96,753 \quad 4,962$

100

5,306

272

100

91,446

4,690

52.2

47,721

2,447

$5.7 \quad 5,194 \quad 266$

$18.9 \quad 17,270 \quad 886$

Note: *Average yield of immature coconut: 17,000 shells/ha/year. Average yield of mature coconut: 10,600 shells/ha/year. Exchange rate in 2010 was VND19,500 to the USD

Intermediate cost in production of mature coconut for processing business is very small in comparison with revenue. Added value accounts for $94.5 \%$ of the revenue. Planting and primary processing produce the highest added value and create jobs for local residents. This implies that by processing coconut in Bến Tre instead of exporting it, more jobs will be created.

Indicators /IC, VA/IC and NPr/IC show that planting and primary processing mature coconut employ mainly local resources (land, labor and capital) and do not rely on external resources. 
Table 3: Economic Efficiency for Every VND1 of Intermediate Cost in all Channels in 2010

\begin{tabular}{lccc}
\hline & Channel 1 & Channel 2 & Channel 3 \\
\hline P/IC & 12.7 & 18.4 & 18.2 \\
VA/IC & 11.7 & 17.4 & 17.2 \\
NPr/IC & 8.0 & 14.5 & 13.2 \\
\hline
\end{tabular}

Source: 2011 survey

\section{d. Analysis of Distribution of Benefits:}

Analysis of benefit distribution in the three channels shows that planters gain reasonable profits (their net profit is much higher than additional cost). Purchasers of level 1 pay more for cost but their gain from interest payment and contributions to selling price are lower. Purchasers of level 2 gain more profit than planters and purchasers 1 do. The share of processing concerns in added cost is much lower than their net profits (Table 4).

Table 4: Distribution of cost and profit in production and trade in Immature Coconut in Bến Tre in 2010 (per 1,000 shells)

Unit: VND1,000

\begin{tabular}{|c|c|c|c|c|c|c|c|c|}
\hline & \multicolumn{3}{|c|}{ Cost } & \multicolumn{3}{|c|}{ Profit } & \multicolumn{2}{|c|}{ Profit margin } \\
\hline & Cost & $\begin{array}{c}\text { Added } \\
\text { cost }\end{array}$ & $\begin{array}{c}\text { Added } \\
\text { cost as } \\
\%\end{array}$ & $\begin{array}{c}\text { Selling } \\
\text { price }\end{array}$ & $\begin{array}{c}\text { Net } \\
\text { profit }\end{array}$ & $\begin{array}{l}\% \text { of } \\
\text { net } \\
\text { profit } \\
\text { as }\end{array}$ & $\begin{array}{l}\text { Market } \\
\text { margin }\end{array}$ & $\begin{array}{c}\text { Contribution } \\
\text { to the price as } \\
\%\end{array}$ \\
\hline \multicolumn{9}{|c|}{ Channel 1: Immature coconut from planter to purchaser of level 2 in Bến Tre City } \\
\hline Planter & 1,409 & 1,409 & 26.7 & 4,000 & 2,603 & 71.0 & 4,000 & 68.6 \\
\hline Purchaser 1 & 4,316 & 2,907 & 55.0 & 4,833 & 517 & 14.1 & 833 & 14.3 \\
\hline Purchaser 2 & 5,286 & 970 & 18.4 & 5,833 & 547 & 14.9 & 1,000 & 17.1 \\
\hline \multicolumn{9}{|c|}{ Channel 2: Mature coconut for export from planter to purchaser 2} \\
\hline Planter & 1,581 & 1,581 & 22.1 & 6,083 & 4,502 & 57.0 & 6,083 & 65.5 \\
\hline Purchaser 1 & 6,343 & 4,762 & 66.7 & 6,833 & 490 & 6.2 & 750 & 8.1 \\
\hline Purchaser 2 & 7,142 & 799 & 11.2 & 9,292 & 2,904 & 36.8 & 2,459 & 26.5 \\
\hline
\end{tabular}


Channel 3: Mature coconut from planter to primary processing concern

$\begin{array}{lcccccccc}\text { Planter } & 1,581 & 1,581 & 21.3 & 6,083 & 4,502 & 68.0 & 6,083 & 67.3 \\ \text { Purchaser 1 } & 6,343 & 4,762 & 64.2 & 6,833 & 490 & 7.4 & 750 & 8.3 \\ \begin{array}{l}\text { Primary processing } \\ \text { concern }\end{array} & 7,415 & 1,072 & 14.5 & 9,045 & 1,629 & 24.6 & 2,212 & 24.5\end{array}$

Source: 2011 survey

\section{e. Gross Financial Efficiency of Value Chain of Bến Tre Coconut:}

Examining coconut planting area, yield and statistics of processed and exported coconut, we could estimate contributions from coconut business to Bến Tre economy. In financial terms (based on 2010 price and data gathered during the survey), the value chain of coconut created an added value of VND4,732 billion (about US\$242.7 million). Of this value, the economy benefited VND1,170 billion (some US\$60 million) in form of wages, bank interest payments, taxes and fees. Participants in the value chain, such as planters, purchasers, primary processing concerns, producers of fiber, coco peat, nata de coco, charcoal, and coconut meat receive an added value of VND3,494 billion (about US\$179 million) as net profit (Table 5).

Regarding the economic efficiency, the value chain of Bến Tre coconut shows a high competitiveness. The $\mathrm{P} / \mathrm{IC}$ ratio of the business is 4.12 , which implies that one dollar spent on intermediate goods produces 4.12 dollars in revenue. Similarly, one dollar invested in intermediate goods creates an added value of 3.12 dollars, and a net profit of 2.98 dollar for direct participants in the chain.

Table 5: Estimate of contribution from coconut business to Bến Tre Economy in 2010 (VND1,000)

\begin{tabular}{lccccccc}
\hline & $\begin{array}{c}\text { Production } \\
\text { scale }\end{array}$ & $\begin{array}{c}\text { Total added } \\
\text { value }\end{array}$ & $\begin{array}{c}\text { As } \\
\text { \% }\end{array}$ & $\begin{array}{c}\text { Added value } \\
\text { for the } \\
\text { economy }\end{array}$ & $\begin{array}{c}\text { As } \\
\mathbf{\%}\end{array}$ & $\begin{array}{c}\text { Net profit for } \\
\text { producers } \\
\text { and } \\
\text { processor }\end{array}$ & $\begin{array}{c}\text { As } \\
\text { \% }\end{array}$ \\
\hline $\begin{array}{l}\text { Immature } \\
\text { coconut }\end{array}$ & 5.000 ha & $457,810,000$ & 9.7 & $146,115,000$ & 12.5 & $311,695,000$ & 8.9 \\
$\begin{array}{l}\text { Mature } \\
\text { coconut for } \\
\text { export }\end{array}$ & $\begin{array}{c}100 \text { million } \\
\text { shells }\end{array}$ & $950,033,333$ & 20.1 & $160,425,926$ & 13.7 & $789,607,407$ & 22.6 \\
Primarily & 25,565 ha & $2,337,838,195$ & 49.4 & $543,532,015$ & 46.4 & $1,794,306,180$ & 51.4
\end{tabular}




\begin{tabular}{|c|c|c|c|c|c|c|c|}
\hline $\begin{array}{l}\text { processed } \\
\text { coconut }\end{array}$ & & & & & & & \\
\hline $\begin{array}{l}\text { Dried } \\
\text { coconut } \\
\text { meat }\end{array}$ & 16,231 tonnes & $68,494,820$ & 1.4 & $28,225,709$ & 2.4 & $40,269,111$ & 1.2 \\
\hline $\begin{array}{l}\text { Coconut } \\
\text { candy }\end{array}$ & 12,000 tonnes & $352,684,800$ & 7.5 & $54,839,200$ & 4.7 & $293,238,400$ & 8.4 \\
\hline Coco peat & 15,900 tonnes & $24,221,727$ & 0.5 & $12,180,454$ & 1.0 & $9,922,786$ & 0.3 \\
\hline $\begin{array}{l}\text { Coconut } \\
\text { fiber }\end{array}$ & 58,889 tonnes & $109,121,111$ & 2.3 & $69,689,111$ & 6.0 & $37,282,556$ & 1.1 \\
\hline $\begin{array}{l}\text { Shell } \\
\text { charcoal, } \\
\text { Activated } \\
\text { charcoal }\end{array}$ & $\begin{array}{c}13,423 \text { tonnes } \\
\text { of pre- } \\
\text { activated } \\
\text { charcoal, } \\
4,474 \text { tonnes } \\
\text { of activated } \\
\text { charcoal }\end{array}$ & $59,817,858$ & 1.3 & $12,899,417$ & 1.1 & $40,781,934$ & 1.2 \\
\hline $\begin{array}{l}\text { Raw nata de } \\
\text { coco }\end{array}$ & $\begin{array}{c}227,944 \\
\text { tonnes }\end{array}$ & $372,688,318$ & 7.9 & $142,692,897$ & 12.2 & $177,112,430$ & 5.1 \\
\hline \multirow[t]{2}{*}{ Total value } & (VND1,000) & $4,732,710,162$ & & $1,170,599,729$ & & $3,494,215,803$ & \\
\hline & (USD) & $242,703,085$ & & $60,030,755$ & & $179,190,554$ & \\
\hline \multirow[t]{2}{*}{$\begin{array}{l}\text { Total value } \\
\text { /ha }\end{array}$} & (VND1,000) & 118,318 & & 29,265 & & 87,355 & \\
\hline & (USD) & 6,068 & & 1,501 & & 4,480 & \\
\hline $\mathrm{P} / \mathrm{IC}$ & 4.12 & & & & & & \\
\hline VA/IC & 3.12 & & & & & & \\
\hline $\mathrm{NPr} / \mathrm{IC}$ & 2.98 & & & & & & \\
\hline
\end{tabular}

Source: 2011 survey

Analysis of the structure of added value in the value chain of Bến Tre coconut shows that three channels (immature coconut, mature coconut for export and primarily processed coconut) account for $80 \%$ of total added value and $73 \%$ of added value for the economy. Channels of processed products also have important contributions. Revenue from these products is considered equal to that from planting and processing mature coconut. Although they account for a smaller share in the total added value 
(20\%), their share in the added value for the economy is pretty high (27.4\%), which shows ability to create jobs of the coconut business. Thus, processing the coconut fully may generate much more socioeconomic benefits than exporting coconut shells.

Analysis of added value from 1,000 coconut shells (Figure 4) shows advantages in production of coconut for industrial purpose and fully processing of coconut products. Immature brings in US $\$ 276$ from 1,000 shells, much lower than revenue from 1,000 mature coconut. Based on 2010 price, revenue from export of dehusked coconut is estimated at US $\$ 487$ for 1,000 shells, higher than the revenue from 1,000 locally processed shells (US\$442). If the coconut is processed more fully to produce dried coconut meat, shell charcoal, activated charcoal, fiber, coco peat and raw nata de coco, 1,000 shells can create an added value of US $\$ 575$. Other integrated products, such as dried coconut meat, pre-activated charcoal, activated charcoal, coconut fiber, coco peat and nata de coco bring in an extra revenue of US $\$ 133$ for every 1,000 shells.

If the balance between exporting and processing the coconut is ensured, Bến Tre can earn an extra US\$88 from 1,000 shells by giving priority to processing the coconut locally over exporting the shells.

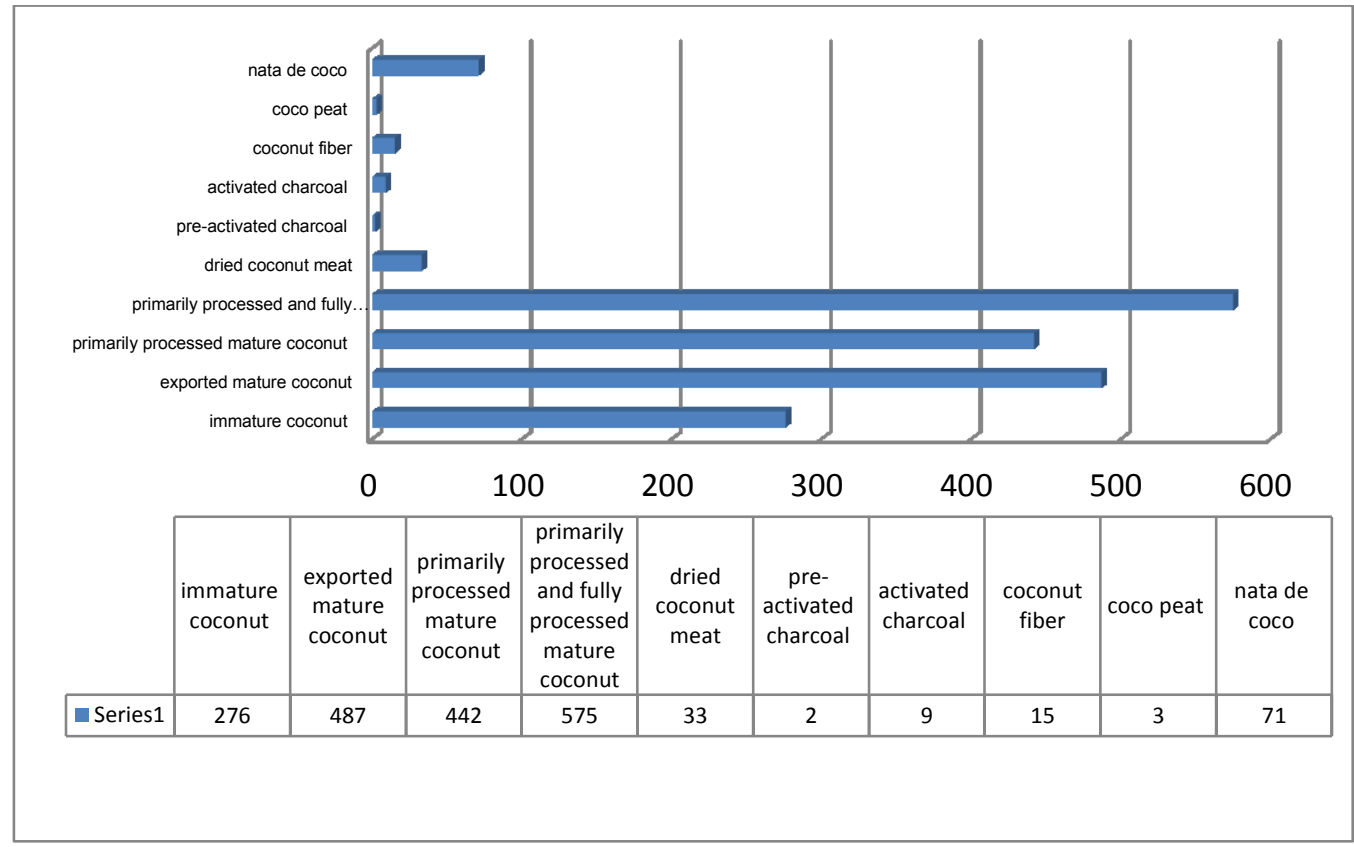

Figure 4: Estimated added value from 1,000 shells in 2010 (US dollar) 


\section{CONCLUSION AND RECOMMENDATIONS}

The results allow us to draw some conclusions about the role of value chain of coconut business in the Bến Tre economy. This business is an important and indispensable part in the socioeconomic development strategy for Bến Tre. This province has good competitive advantages for development of the coconut business to generate new jobs and sources of income for local residents. The analysis of distribution of benefit in three channels - immature coconut, mature coconut for export and primarily processed mature coconut - shows that coconut planters receive reasonable profit. Vertical linkage, however, is not good enough in the value chain. Purchasers and processors of coconut play a leading role in supply of raw materials to processing concerns while these concerns determine development of the value chain.

When the world market for coconut products is stable as in 2010, the value chain of coconut creates huge economic resources for Bến Tre. It is estimated that it brings in some VND4,000 billion of added value by exporting coconut and producing products from coconut. Fully processed goods certainly generates more added value than semifinished products and the value chain of Bến Tre coconut has good competitiveness by making the best use of local resources. All indicators show competitiveness in terms of price by Bến Tre coconut products on the world market.

To ensure stability and sustainable development for Bến Tre coconut industry and control risks such as a sharp decline in the world coconut market in 2011 caused by the global economic recession, local authorities should develop a development plan for the coconut industry in the future, introduce measures to ensure sources of shells as raw materials, and modernize technology of coconut processing business to diversify coconut products before positioning markets and products, promoting trade and investing in production of coconut products of higher added value

\section{References}

Bến Tre Statistics Office (2010), Niên giám thống kê năm 2009 (Statistical Yearbook 2009).

GTZ (2007), Value Links Manual: The Methodology of Value Chain Promotion, First Edition.

M4P (2008), Making Value Chains Work Better for the Poor, A Toolbook for Practitioners of Value

Chain Analysis, $3^{\text {rd }}$ Version, Making Markets Work Better for the Poor (M4P) Project, UK

Department for International Development (DFID), Agricultural Development International,

Phnom Penh, Cambodia.

Tallec, Fabien \& L. Bockel (2005), Commodity Chain Analysis, EASYPol, Modules 043-046, FAO. 